\title{
AKAR PERMASALAHAN TIDAK TERPENUHINYA PERMINTAAN BABY BUNCIS PERUSAHAAN MITRA OLEH GAPOKTAN WARGI PANGGUPAY
}

\section{THE ROOT OF THE PROBLEM IS NOT FILLING THE DEMAND OF BABY BUNCIS PARTNERS BY GAPOKTAN WARGI PANGGUPAY}

\author{
Lathifah Nur*, Lucyana Trimo \\ Program Studi Agribisnis, Fakultas Pertanian, Universitas Padjadjaran \\ *E-mail: lathifahnur@gmail.com \\ (Diterima 16-1-2021; Disetujui 26-1-2021)
}

\begin{abstract}
ABSTRAK
Menurut data BPS (2018), ekspor hortikultura periode Januari-Desember 2018 mengalami peningkatan sekitar 10\% jika dibandingkan tahun 2017 lalu. Peningkatan volume tersebut dipengaruhi volume ekspor sayuran segar di Bandung Barat yang mencapai 1.500 ton pada tahun tersebut. Didukung oleh pemerintah pusat dan daerah, lahan yang luas dan subur di kawasan Lembang, Gabungan Kelompok Usahatani (Gapoktan) Wargi Panggupay mengusahakan baby buncis sebagai komoditas unggulan untuk memenuhi permintaan akan baby buncis perusahaan mitra. Permasalahan yang sering dihadapi petani baby buncis yaitu dalam memasok baby buncis dengan kualitas layak ekspor secara berkesinambungan dan jumlah baby buncis yang dipasok belum memenuhi target jumlah permintaan perusahaan ekspor. Tujuan dari penelitian ini adalah untuk mengetahui akar permasalahan dari tidak terpenuhinya permintaan baby buncis perusahaan mitra di Gapoktan Wargi Panggupay. Objek penelitian dari penelitian ini adalah akar permasalahan tidak terpenuhinya permintaan baby buncis perusahaan mitra oleh Gapoktan Wargi Panggupay. Tempat penelitian ini beralamat di Kampung Gandok RT 01 RW 15 Desa Suntenjaya, Kecamatan Lembang, Kabupaten Bandung Barat, Provinsi Jawa Barat. Desain penelitian yang digunakan adalah desain kualitatif dengan teknik penelitian studi kasus. Data yang digunakan merupakan data primer dan data sekunder yang diperoleh dari wawancara mendalam, observasi, dokumentasi, dan kepustakaan. Peneliti menggunakan metode analisis kualitatif dengan pendekatan deskriptif dan diagram fishbone untuk mencari akar permasalahan. Hasil dari penelitian ini yang termasuk akar masalah penyebab utama tidak terpenuhinya permintaan baby buncis perusahaan mitra, yaitu: (1) petani mempersepsikan penerapan SOP budidaya baby buncis itu rumit, (2) penggunaan alat pertanian yang masih tradisional, (3) musim kemarau dan musim hujan.
\end{abstract}

Kata kunci: Akar Permasalahan, Diagram Fishbone, Baby Buncis, Petani

\begin{abstract}
According to BPS data (2018), horticultural export volume for the January-December 2018 period had increased about 10\% compared to that of 2017. This increase in volume is largely influenced by fresh vegetable exports from West Bandung which reaches 1,500 tons on that year. Supported by local and center government, wide and fertile land in Lembang area, Gapoktan Wargi Panggupay, cultivates baby beans as a superior commodity to meet the demand for baby beans from abroad. The problem often faces by baby bean farmers is in continuity of quantity supplied with export-quality. The purpose of this study is to describe the possible cause of the unfulfilled demand for baby beans by Gapoktan Wargi Panggupay. The aim of this research is the find the root cause why Gapoktan Wargi Panggupay is not always able to meet the demand. The research conducted in Kampung Gandok RT 01 RW 15 Suntenjaya Village, Lembang District, West Bandung Regency, West Java Province. The research design used is a qualitative design with a case study research technique. The data used are primary data and secondary data obtained from in-depth interviews, observation, documentation, and literature. Researchers used qualitative analysis methods with descriptive approaches and fishbone diagrams to find the root of the
\end{abstract}


problem. The results of this study reveal that the root cause of the problem are: (1) farmers perceive the implementation of SOP for baby bean cultivation to be complicated, (2) use of traditional agricultural tools, (3) dry and rainy seasons.

Keywords: Root Problems, Fishbone Diagram, Baby Beans, Farmer

\section{PENDAHULUAN}

Menurut data BPS (2018), ekspor hortikultura periode Januari-Desember 2018 mengalami peningkatan sebesar $10 \%$ jika dibandingkan dengan tahun 2017 lalu. Peningkatan ini banyak dipengaruhi volume ekspor sayuran segar di Bandung Barat. Volume ekspor untuk sayuran mencapai 1.500 ton setahun atau 3,5-4 ton per harinya. Didukung dengan potensi pengembangan sayuran yang tinggi di daerah Lembang yang memiliki lahan pertanian sangat luas dan subur serta adanya dukungan tinggi dari pemerintah pusat dan daerah.

Potensi ini dimanfaatkan petani di Lembang mengusahakan baby buncis sebagai komoditas unggulan yang memiliki nilai jual dan potensi yang tinggi untuk dapat diekspor ke pasar internasional. Kelompok tani baby buncis bekerja sama dengan perusahaan mitra sebagai pihak eksportir untuk memasarkan hasil panennya. Salah satu Gabungan Kelompok Usahatani (Gapoktan) yang memenuhi permintaan akan baby buncis perusahaan mitra adalah Gapoktan Wargi Panggupay.
Kerjasama dengan perusahaan mitra, seperti PT. Alamanda Sejati Utama, PT. Corona, PT. Momenta Agricultura, dan Fortuna Agro Mandiri mampu membuat baby buncis yang diusahakan Gapoktan Wargi Panggupay menembus pasar ekspor. Gapoktan Wargi Panggupay yang diketuai oleh Ulus Pirmawan selain mampu mengekspor baby buncis ke Singapura, juga mampu mensejahterahkan seluruh anggota kelompok taninya.

Permasalahan yang sering dihadapi petani baby buncis ada pada pasokan baby buncis. Permasalahan itu berupa kesulitan petani dalam memasok baby buncis dengan kualitas layak ekspor secara berkesinambungan. Permasalahan lain ada pada jumlah baby buncis yang dipasok belum memenuhi target jumlah permintaan perusahaan ekspor agar dapat beroperasi secara efisien.

Tujuan dari penelitian ini adalah untuk mengetahui akar permasalahan dari tidak terpenuhinya permintaan baby buncis perusahaan mitra di Gapoktan Wargi Panggupay. 
Buncis atau Phaseolus vulgaris L. merupakan makanan legum yang paling penting untuk dikonsumsi langsung di dunia. Tanaman buncis merupakan tanaman semusim yang memiliki bentuk perdu. Buncis memiliki lebih dari 40.000 varietas. Phaseolus vulgaris biasanya diproduksi di daerah Amerika Latin, Afrika, Timur Tengah, Cina, Eropa, Amerika Serikat, dan Kanada. (FAO, 1999).

Buncis termasuk kelompok kacangkacangan yang digemari masyarakat karena sumber protein nabati dan kaya akan vitamin A, B, dan C. Buncis memberi peranan dan sumbangan besar bagi pendapatan para petani, kaya akan gizi, pendapatan negara dengan adanya ekspor yang tinggi, berkembangnya agribisnis, dan membuka lapangan pekerjaan. Sehingga buncis sangat bermanfaat sebagai bahan makanan bagi kesehatan masyarakat Indonesia. Alasan inilah yang menjadikan buncis sebagai sayuran yang memiliki prospek yang baik dan perlu untuk dikembangkan.

Kondisi buncis yang siap panen adalah pada saat polong belum mencapai kematangan sempurna. Untuk mendapatkan hasil buncis yang tinggi, polong harus mencapai panjang maksimumnya selama masih sukulen dan pembesaran biji belum terlihat nyata. Waktu panen dihitung dengan metode menghitung hari setelah tanaman mekar secara keseluruhan. Untuk polong buncis dipanen saat 14-18 hari setelah terbentuk polong. Menurut Setianingsih dan Khaerudin (2002), pemanenan dilakukan saat umur tanaman 60 hari dengan ciriciri warna polong agak muda, permukaan kulit kasar, biji polong belum terlihat meninjol, polong belum berserat dan jika dipatahkan akan timbul bunyi letup. Idealnya baby buncis dipanen seminggu empat kali. Pada proses panen diperlukan kelitian dengan tujuan menghindari kerusakan dan tangkai tidak patah pada baby buncis. Kualitas baby buncis akan menurun jika baby buncis dibiarkan tumbuh dan tidak dipanen setelah 45-50 hari setelah ditanam.

Menurut Eunike et al (2018), perencanaan produksi merupakan suatu aktivitas mengevaluasi fakta di masa lalu dengan yang sekarang dan mengantisipasi adanya perubahan kecenderungan pada masa yang akan datang untuk menetapkan strategi dan penjadwalan proses produksi yang secara tepat guna dapat mewujudkan sasaran pemenuhan permintaan dengan efektif serta efisien. Pada perencanaan produksi terdapat aktivitas seperti perencanaan 
jumlah produk yang akan diproduksi, kapan produk tersebut selesai, dan material apa saja yang dibutuhkan pada proses produksi.

Menurut Ginting (2007), tujuan perencanaan produksi adalah: (1) sebagai langkah pertama penentuan aktivitas produksi adalah menjadi referensi lebih rinci dari rencana agregat menjadi sebuah item dalam jadwal induk produksi, (2) sebagai masukan rencana sumber daya sehingga perencanaan sumber daya dapat dikembangkan untuk mendukung proses perencanaan produksi, (3) Meredam produksi dan tenaga kerja terhadap adanya fluktuasi permintaan.

Salah satu usaha yang dilakukan dalam pengembangan agribisnis hortikultura adalah program kemitraan. Menurut Peraturan Pemerintah No. 44 tahun 1997, kemitraan adalah kerjasama antara usaha kecil dengan usaha menengah ataupun besar dengan prinsip saling memerlukan, memperkuat, dan menguntungkan. Menurut Qonita (2012), kemitraan merupakan bentuk kerjasama perusahaan inti dengan petani sebagai mitranya dengan disertai adanya pembinaan dan pengembangan yang kontinuitas dan saling menguntungkan kedua belah pihak.
Kemitraan usaha pertanian terbagi menjadi 5 pola berdasarkan pasal 4 Keputusan Menteri Pertanian Republik Indonesia nomor 940/KPTS/OT.210/10/97 tentang pedoman kemitraan usaha pertanian, yaitu (1) pola inti plasma, (2) pola subkontrak, (3) pola dagang umum, (4) pola keagenan, (5) pola kerjasama.

Menurut Purnaningsih dan Sugihen (2008), manfaat dari kemitraan perusahaan dengan petani terbagi menjadi manfaat secara ekonomi dan sosial. Manfaat kemitraan secara ekonomi, yaitu: (1) peningkatan pendapatan petani dikarenakan adanya pendampingan dan pembinaan dari perusahaan mitra untuk meningkatkan produksi, (2) memperoleh pasar yang pasti sehingga menciptakan harga yang lebih pasti, (3) risiko usaha dalam pengolahan dan pemasaran yang ditanggung bersama. Sedangkan manfaat kemitraan secara social, yaitu: (1) keberlanjutan kerjasama karena manfaat telah dirasakan petani mitra dalam memperoleh pasar yang pasti dan kepastian harga, (2) upaya pelestarian lingkungan, karena input produksi yang digunakan berasal dari alam sehingga tidak merusak agoekosistem yang ada. 
Pengendalian kuantitas pada input produksi biasa digunakan dalam industri. Pada negara berkembang, perizinan impor dan kontrol devisa dapat membatasi kuantitas input yang tersedia untuk perusahaan domestik. Sedangkan pada negara industri, pengendalian kuantitas digunakan untuk mengatur industri sumber daya alam. Inti dari pengendalian kuantitas adalah memproduksi sejumlah yang dibutuhkan. Meskipun pengendalian kuantitas sering digunakan, namun teori ini belum banyak dipelajari.

Pengendalian kuantitas merupakan aspek penting dalam berhubungan dengan pemasok. Tujuannya untuk memastikan terpenuhinya kewajiban kontrak dan mencegah adanya perselisihan dalam jangka panjang.

Berikut adalah faktor-faktor yang mempengaruhi pengendalian kuantitas: (1) pengontrolan input produksi, (2) metode produksi yang digunakan, (3) kualitas dari ouput yang dihasilkan, (3) produktivitas para tenaga kerja, (4) energi yang dikeluarkan untuk produksi

Menurut Assauri (2004), kualitas merupakan sebagian dari kumpulan dan sejumlah sifat yang mendeskripsikan bentuk produk atau jasa yang dihasilkan. Menurut Ariani (2005), pengendalian kualitas merupakan sebuah proses bisnis yang penting dikarenakan adanya tuntutan konsumen modern dalam tuntutan kualitas produk pertanian yang baik.

Berikut adalah faktor-faktor yang mempengaruhi kualitas suatu produk:

a. Manusia

Sumber daya manusia adalah faktor terpenting bagi sebuah perusahaan yang memungkinan terjadi penambahan nilai pada sebuah produk yang dihasilkan. Menurut Prawirosentono (2002), kemampuan manusia yang terlibat dalam proses penambahan nilai dipengaruhi pengalaman, keragaman kemampuan, potensi, pelatihan, dan kreativitas yang dimiliki individu.

b. Metode

Menurut Prawirosentono (2002), metode diartikan sebagai prosuder kerja dari tugas yang diemban masing-masing pekerja. Metode yang diaplikasikan sebuah perusahaan berupa prosedur kerja terbaik agar tiap pekerja dapat menyelesaikan tugasnya dengan baik.

c. Bahan baku

Bahan baku sangat berpengaruh dalam kegiatan produksi. Sebuah perusahaan tidak dapat berproduksi tanpa ada bahan baku. Bahan baku adalah seluruh komponen masukan yang 
digunakan untuk menghasilkan suatu produk (Khomah, 2009).

d. Lingkungan

Lingkungan kerja adalah lingkungan fisik pekerja yang mempengaruhi keamanan, kinerja, dan mutu kehidupan kerja. Terdapat juga faktor-faktor lingkungan kerja dibawah kendali organisasi dan manajer operasi, seperti suhu, kelembaban, suara dan getaran, dan pencahayaan (Heizer dan Render, 2004).

\section{METODE PENELITIAN}

Objek penelitian dari penelitian ini adalah akar permasalahan tidak terpenuhinya permintaan baby buncis. Tempat penelitian ini beralamat di Kampung Gandok RT 01 RW 15 Desa Suntenjaya, Kecamatan Lembang, Kabupaten Bandung Barat, Provinsi Jawa Barat. Desain penelitian yang digunakan pada penelitian ini adalah desain kualitatif. Teknik penelitian yang digunakan pada penelitian ini adalah studi kasus.

Berikut adalah batasan variabel yang akan diteliti:

- Perencanaan produksi adalah keputusan terkait proses produksi baby buncis di masa yang akan mendatang meliputi apa yang harus dilakukan, berapa banyak yang harus diproduksi, dan kapan melakukannya.

- Kemitraan adalah kerjasama antara Gapoktan Wargi Paggupay dengan perusahaan eksportir sebagai partner kerja yang saling menguntungkan, memerlukan, dan memperkuat.

- Pengendalian kuantitas adalah proses pengecekan seberapa jauh kuantitas baby buncis yang diproduksi sesuai dengan permintaan perusahaan mitra agar kewajiban kontrak terpenuhi.

- Pengendalian kualitas adalah proses pengecekan seberapa jauh kualitas baby buncis yang diproduksi sesuai dengan kriteria layak ekspor agar kewajiban kontrak terpenuhi.

- Manusia adalah salah satu faktor produksi penting yang dapat mempengaruhi penambahan nilai pada baby buncis.

- Bahan baku adalah sarana produksi pertanian untuk memproduksi baby buncis berupa benih, pupuk, pestisida, dan air.

- Metode produksi adalah prosedur kerja dalam proses produksi baby buncis dengan memanfaatkan berbagai sarana yang ada.

- Lingkungan adalah kondisi alam yang berpengaruh pada kegiatan usahatani 
dan hasil panen dari baby buncis, berupa cuaca dan angin besar.

- Kualitas baby buncis layak ekspor adalah karakteristik baby buncis yang memenuhi persyaratan ekspor dilihat dari ukuran baby buncis, bentuk buah, bentuk dan warna polong buah, kondisi fisik buah, keamanan untuk dikonsumsi, dan kecacatan buah.

- Diagram fishbone adalah alat analisis kualitatif yang bertujuan untuk menggambarkan hubungan dari permasalahan yang terjadi dengan kemungkinan penyebabnya dan faktor yang mempengaruhinya mengenai kualitas baby buncis layak ekspor.

Data yang digunakan pada penelitian ini merupakan data primer dan data sekunder. Untuk mendapatkan data primer dan sekunder, peneliti menggunakan wawancara mendalam, observasi, dokumentasi, dan kepustakaan. Pada penelitian ini, peneliti menggunakan metode analisis kualitatif dengan pendekatan deskriptif untuk mengolah data. Penelitian ini juga menggunakan diagram fishbone untuk mencari akar permasalahan dari tidak terpenuhinya permintaan baby buncis perusahaan mitra yang terjadi di Wargi Panggupay.

\section{HASIL DAN PEMBAHASAN}

Permasalahan yang dihadapi oleh Gapoktan Wargi Panggupay adalah kesulitan petani dalam memasok baby buncis dengan kualitas layak ekspor dan kuantitas sesuai permintaan secara berkesinambungan karena hasil produksi yang berfluktuasi. Saat kekurangan hasil produki, baby buncis yang tidak terpenuhi bisa mencapai angka 50\%.

Secara kualitas, berikut adalah ciriciri baby buncis yang memenuhi kriteria layak ekspor : memiliki panjang minimal 13-15 cm, fisik mulus tanpa cacat (tidak bolong dan terdapat goresan), bentuk buncis lurus tidak bengkok dan seperti berotot, berwarna hijau tua, serta bebas dari serangan hama dan penyakit tanaman.

Berdasarkan diagram fishbone, dapat diketahui bahwa faktor-faktor penyebab utama dikelompokkan menjadi bahan mentah/bahan baku, mesin, tenaga kerja, metode, dan lingkungan. Rincian dari kelima faktor tersebut adalah:

\section{Bahan Mentah/Bahan Baku}

a) Penyemprotan pestisida tidak sesuai kebutuhan

Penyemprotan pestisida, khususnya fungisida dan insektisida harus sesuai dengan Pengendalian Hama Terpadu (PHT). Jika penyemprotan tidak sesuai 
kebutuhan, hal ini bisa menyebabkan tanaman baby buncis tidak masuk kriteria layak ekspor karena memiliki residu tinggi. Nyatanya petani hanya menerapkan penyemprotan secara intensif tanpa memperhatikan kadar toksin pestisida terhadap keamanan baby buncis untuk dikonsumsi.

Sebagian kecil petani merasa rumit dalam penyemprotan pestisida sesuai kebutuhan. Petani mempersepsikan budidaya baby buncis sesuai SOP itu rumit. Berdasarkan hasil penelitian Charina, dkk. (2018), persepsi petani terhadap kerumitan berpengaruh positif dan signifikan terhadap keputusan petani dalam menerapkan SOP.

b) Mengabaikan penggunaan ajir dan plastik mulsa

Pemakaian ajir dan plastik mulsa sering diabaikan oleh petani. Menurut Saparinto (2013), buncis adalah tanaman yang merambat sehingga diperlukan ajir agar dapat merambat dengan rapih. Pada musim hujan plastik mulsa berfungsi mencegah erosi pada permukaan bedengan, sedangkan pada musim kemarau dapat menahan panas matahari secara langsung agar permukaan tanah bagian atas lembab dan relatif bersuhu rendah. Walaupun SOP sudah diberikan, sebagian kecil petani merasa rumit dalam penggunaan ajir dan plastik mulsa, sehingga beberapa petani memilih untuk tidak menggunakan ajir dan plastik mulsa.

c) Penggunaan pupuk kompos tidak sesuai anjuran

Petani biasanya cenderung instan dalam kegiatan usahatani, salah satunya dalam penggunaan pupuk kandang. Dalam penggunaan pupuk kandang petani sering mengaplikasikan langsung kotoran ternak yang masih segar tanpa difermentasikan dahulu. Faktanya kotoran yang baru keluar dari perut ternak tidak boleh langsung digunakan karena masih dalam proses penguraian yang menimbulkan peningkatan suhu. Petani mempersepsikan budidaya baby buncis sesuai SOP itu rumit. Hal ini mempengaruhi keputusan petani menerapkan SOP yang telah diberikan.

\section{Tenaga Kerja}

a) Ketidaktelitian petani dalam memetik Pada saat panen baby buncis diperlukan ketelitian cara memetik baby buncis agar tidak ada yang terpotong bagian pangkalnya. Tujuan dari tuntutan hati-hati dalam memetik adalah agar umur simpan baby buncis menjadi lebih lama. Jumlah tenaga kerja profesional yang terkontrak di Gapoktan Wargi Panggupay terbatas. Tidak banyak petani 
yang paham mengenai cara panen yang baik. Berkurangnya jumlah tenaga kerja disebabkan ketidakseimbangan jumlah petani dan buruh tani. Buruh tani yang menjadi pemetik baby buncis didominasi oleh buruh tani yang tidak profesional. Kurangnya buruh tani profesional disebabkan mereka sudah beralih profesi menjadi pengusaha tani.

b) Kekurangan tenaga kerja

$$
\text { Kurangnya tenaga kerja }
$$
menyebabkan pekerjaan di kebun membutuhkan waktu yang lebih lama. Seperti kurangnya tenaga kerja pada saat panen baby buncis. Apabila terdapat kekurangan jumlah tenaga kerja, proses panen dapat membutuhkan waktu lebih panjang dari biasanya. Berkurangnya jumlah tenaga kerja disebabkan jumlah buruh tani berkurang. Para buruh tani yang biasa mengerjakan, sudah meninggalkan posisi buruh taninya dan menjadi pengusaha tani. Sehingga tiap petani yang memiliki lahan membutuhkan buruh tani.

\section{Metode}

a) Pengolahan tanah yang kurang baik

Berdasarkan penelitian Nadapdap (2012), pengolahan lahan seperti jarak bedengan dan ukuran bedengan berpengaruh terhadap suatu standar kualitas baby buncis. Tanah yang akan ditanami baby buncis harus gembur dengan ketinggian minimal 50-70 $\mathrm{cm}$. Tanah yang sudah gembur kemudian dibuat bedengan dengan cangkul. Umumnya lebar bedengan yaitu 80-100 cm dengan tinggi $30-50 \mathrm{~cm}$, dan jarak antar bedengan 50-60 $\mathrm{cm}$. Penggunaan alat pertanian tradisional menyebabkan pengolahan tanah kurang baik. Pemakaian tenaga manusia dengan alat bantu cangkul untuk mengolah tanah dalam jangka waktu yang panjang akan mengakibatkan produktivitas dalam bekerja kurang konsisten.

\section{Lingkungan}

a) Musim kemarau dan musim hujan

Pada penelitian Kartiwa (2016), kondisi alam yang merupakan faktor teknis berpengaruh terhadap hasil panen dan kegiatan usahatani baby buncis. Musim kemarau yang berkepanjangan dapat menyebabkan tanaman kekurangan air sehingga jumlah produksi dan kualitas yang dihasilkan rendah. Akibatnya disaat ada permintaan baby buncis, gapoktan tidak dapat memenuhinya. Sedangkan musim hujan terus-menerus dapat menyebabkan pekerjaan di kebun tersendat dan bunga tanaman rontok. Penyinaran matahari yang minim menyebabkan kegiatan fotosintesis berkurang. 
b) Angin besar

Angin besar yang terjadi pada saat hujan turun juga bisa memberi dampak buruk bagi baby buncis. Tanaman yang seharusnya tegak bisa menjadi miring karena terkena terpaan angin. Akibat jangka panjangnya yaitu berdampak pada pertumbuhan baby buncis dan hasil baby buncis yang akan dipanen. Buah baby buncis yang terkena angin besar dapat menyebabkan fisiknya cacat seperti terkena goresan sehingga tidak memenuhi kriteria layak ekspor.

c) Hama dan penyakit tanaman

Hama yang sering menyerang tanaman baby buncis adalah ulat buah. Awalnya ulat buah akan menyerang bagian daun baby buncis hingga berlubang. Kedepannya jika ulat buah didiamkan dapat menyebabkan buah baby buncis juga berlubang. Penyakit yang dikarenakan hama sering menyerang baby buncis di Desa Suntenjaya yaitu patek. Penyakit ini mengakibatkan permukaan polong baby buncis terdapat bitnik hitam. Serangan hama dan penyakit tanaman disebabkan faktor pengerjaan dari awal tidak sesuai SOP, seperti pemakaian pupuk yang masih mentah dan pencangkulan secara asal. Hal ini yang mengakibatkan pertumbuhan baby buncis tidak sehat, sehingga cepat terkena serangan hama dan penyakit. Ketidakpatuhan petani dalam menerapkan SOP disebabkan petani mempersepsikan budidaya baby buncis sesuai SOP itu rumit.

Berikut adalah diagram fishbone dari akar permasalahan tidak terpenuhinya permintaan baby buncis pada Gambar 1.

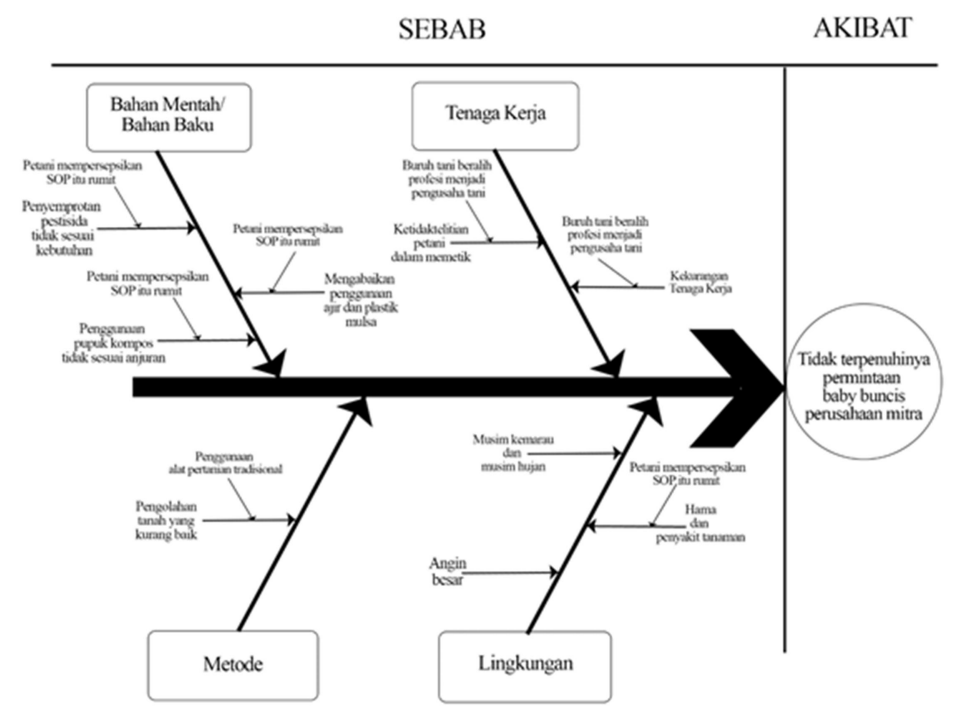

Gambar 1. Diagram Fishbone Tidak Terpenuhinya Permintaan Baby Buncis Perusahaan Mitra

Pada Tabel 1 merupakan hasil diskusi pencarian akar permasalahan tidak terpenuhinya permintaan baby buncis perusahaan mitra dengan ketua Gapoktan Wargi Panggupay. Dilihat pada Tabel 1, akar permasalahan yang merupakan penyebab utama tidak terpenuhinya permintaan baby buncis perusahaan mitra diberi tanda huruf $\mathrm{Y}$ (Ya), sedangkan akar permasalahan yang bukan penyebab utama tidak 
terpenuhinya permintaan baby buncis perusahaan mitra diberi tanda huruf $\mathrm{T}$ (Tidak). Akar masalah yang diberi tanda huruf $\mathrm{Y}$ merupakan akar masalah menurut hasil diskusi dan selanjutnya diberi lingkaran merah pada diagram fishbone-nya. Tujuannya adalah agar pihak Gapoktan Wargi Panggupay dapat lebih mudah mengetahui penyebab tidak terpenuhinya permintaan baby buncis perusahaan mitra.

Tabel 1. Diskusi Diagram Fishbone Dalam Mencari Akar Permasalahan

\begin{tabular}{|c|c|c|}
\hline $\begin{array}{l}\text { Kemungkinan } \\
\text { Penyebab }\end{array}$ & $\begin{array}{l}\text { Diskusi Akar } \\
\text { Permasalahan }\end{array}$ & $\begin{array}{l}\text { Akar } \\
\text { Masalah? }\end{array}$ \\
\hline \multicolumn{3}{|c|}{ Bahan Mentah/Bahan Baku } \\
\hline $\begin{array}{l}\text { Penyemprotan } \\
\text { pestisida tidak } \\
\text { sesuai kebutuhan }\end{array}$ & $\begin{array}{l}\text { Petani } \\
\text { mempersepsikan } \\
\text { SOP itu rumit }\end{array}$ & $\mathrm{Ya}$ \\
\hline $\begin{array}{l}\text { Mengabaikan } \\
\text { penggunaan ajir } \\
\text { dan plastik mulsa }\end{array}$ & $\begin{array}{l}\text { Petani } \\
\text { mempersepsikan } \\
\text { SOP itu rumit }\end{array}$ & $\mathrm{Ya}$ \\
\hline Penggunaan & Petani & $\mathrm{Ya}$ \\
\hline $\begin{array}{lr}\text { pupuk } & \text { kompos } \\
\text { tidak } & \text { sesuai } \\
\text { anjuran } & \\
\end{array}$ & $\begin{array}{l}\text { mempersepsikan } \\
\text { SOP itu rumit }\end{array}$ & \\
\hline \multicolumn{3}{|l|}{ Tenaga Kerja } \\
\hline $\begin{array}{l}\text { Ketidaktelitian } \\
\text { petani dalam } \\
\text { memetik }\end{array}$ & $\begin{array}{l}\text { Buruh tani } \\
\text { beralih profesi } \\
\text { menjadi } \\
\text { pengusaha tani }\end{array}$ & Tidak \\
\hline $\begin{array}{l}\text { Kekurangan } \\
\text { tenaga kerja }\end{array}$ & $\begin{array}{l}\text { Buruh tani } \\
\text { beralih profesi } \\
\text { menjadi } \\
\text { pengusaha tani }\end{array}$ & Tidak \\
\hline \multicolumn{3}{|l|}{ Metode } \\
\hline $\begin{array}{l}\text { Pengolahan } \\
\text { tanah yang } \\
\text { kurang baik }\end{array}$ & $\begin{array}{l}\text { Penggunaan alat } \\
\text { pertanian } \\
\text { tradisional }\end{array}$ & $\mathrm{Ya}$ \\
\hline \multicolumn{3}{|l|}{ Lingkungan } \\
\hline $\begin{array}{l}\text { Musim kemarau } \\
\text { dan musim hujan }\end{array}$ & & Ya \\
\hline $\begin{array}{l}\text { Hama dan } \\
\text { penyakit } \\
\text { tanaman }\end{array}$ & $\begin{array}{l}\text { Petani } \\
\text { mempersepsikan } \\
\text { SOP itu rumit }\end{array}$ & Tidak \\
\hline Angin besar & & Tidak \\
\hline
\end{tabular}

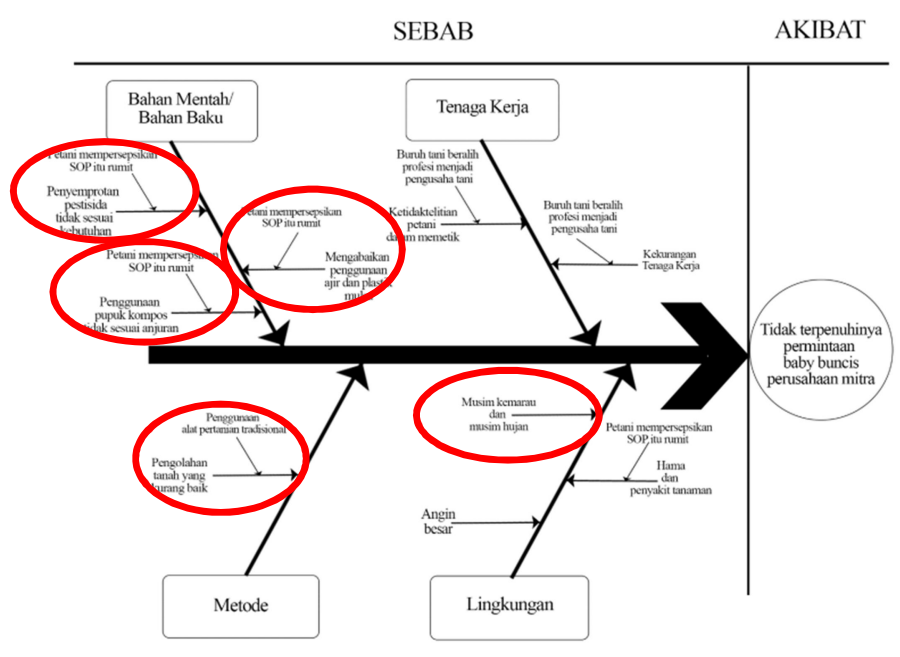

Gambar 2. Diagram Fishbone - Melingkari Akar Permasalahan

Berdasarkan hasil analisis diagram fishbone pada Gambar 2, akar masalah penyebab utama tidak terpenuhinya permintaan baby buncis perusahaan mitra adalah:

- Petani mempersepsikan penerapan SOP budidaya baby buncis itu rumit

- Penggunaan alat pertanian yang masih tradisional

- Musim kemarau dan musim hujan

\section{KESIMPULAN DAN SARAN}

Berdasarkan uraian di atas, maka dapat ditarik kesimpulan dalam penelitian yaitu yang merupakan akar masalah penyebab utama tidak terpenuhinya permintaan baby buncis perusahaan mitra terdiri dari: (1) petani mempersepsikan penerapan SOP budidaya baby buncis itu rumit, (2) penggunaan alat pertanian yang 
masih tradisional, (3) musim kemarau dan musim hujan.

Berdasarkan kesimpulan penelitian di atas, maka dapat diajukan rekomendasi kebijakan berupa: (1) diadakan penyuluhan dengan metode gabungan demonstrasi cara dan hasil yang terfokus pada penerapan SOP budidaya baby buncis, (2) pemberian penghargaan bagi kelompok tani yang menunjukkan hasil kerja terbaik serta pemberian bonus berupa materi, (3) diadakan briefing di pagi hari kepada para petani, (4) pembuatan gambaran flowchart produksi baby buncis yang dapat diletakkan di tempat yang mudah terlihat oleh petani, (5) perlu adanya pengetatan pengawasan yang dilakukan penanggung jawab mulai dari pengolahan tanah hingga proses panen, (6) adanya sanksi kepada petani yang melanggar ketentuan SOP, (7) membuat shift kerja pada bagian pengolahan tanah setiap dua jam sekali untuk tiap petani.

\section{DAFTAR PUSTAKA}

Nadapdap, Johannes H. (2012). Faktor Faktor Yang Mempengaruhi Pengendalian Kualitas Baby Buncis Untuk Memenuhi Pasar Ekspor. Jurnal Agribisnis dan Pengembangan Wilayah, 4(1): 112.

Kartiwa, N. A. R., dan Djuwendah, E. (2016). Faktor Penyebab
Ketidakmampuan Petani Memenuhi Permintaan Babybuncis Untuk PT. Alamanda Sejati Utama Serta Strategi Untuk Mengatasinya (Studi Kasus Kelompok Tani Tauhid, Kabupaten Bandung Barat). Jurnal Social Economic of Agriculture, 5(1) : 28-38.

Sari, Nabilah I, dkk. (2015). Pengendalian Mutu Bayam Sistem Hidroponik Di PT. Kebun Sayur Segar Kabupaten Bogor Provinsi Jawa Barat. AGRISTA, 3(3) : 342353.

Rochdiani, Dini dan Suranta, Kenal Junius. (2007). Pola Kemitraan Antara Petani Padi dengan PT. EFarm Bisnis Indonesia Dalam Meningkatkan Pendapatan Petani Padi. Sosiohumaniora, 9(1) : 1-6.

Sonalia, D., dan Hubeis, M. (2016). Pengendalian Mutu Pada Proses Produksi Di Tiga Usaha Kecil Menengah Tahu Kabupaten Bogor. Jurnal Manajemen Dan Organisasi, 4(2) : 112-127.

Yuanita, Fristy dan Mukti, Gema W. (2012). Pengendalian Kualitas Pada Rantai Pasok Sayuran Selada Dengan Teknik Budidaya Hidroponik NFT (Studi Kasus di PT. Momenta Agrikultura "Amazing Farm", Kecamatan Lembang Kabupaten Bandung Barat, Jawa Barat). Jurnal Agrosains dan Teknologi, 2(1) : 2342.

Charina, Anne, dkk. (2018). Faktorfaktor yang Mempengaruhi Petani dalam Menerapkan Standar Operasional Prosedur (SOP) Sistem Pertanian Organik di Kabupaten Bandung Barat. Jurnal Penyuluhan, 14(1) : 68-78.

Hermawati, Ufik, dkk. (2016). Persepsi Petani Terhadap Karakteristik Pupuk Organik Cair Limbah Etanol 
Di Kecamatan Mojolaban. AGRISTA, 4(3) : 1-12.

Jasmine, Latief dan Trimo, Lucyana. (2019). Faktor Penghambat Penerapan Good Manufacturing Practices Pada Proses Pengendalian Kualitas Bandrek Di CV. X. Agrointek, 13(2) : 155-167.

Jayanti, Hadis dan Ngurah, Dewa. (2009). Upaya Meminimalisir Dampak Lingkungan Dari Penggunaan Pestisida Dalam Pertanian (Dampak Lingkungan Dan Penanggulangannya). Agrica, 2(1) : 14-21.

Nugroho, Purwono. (2017). Pengaruh Standar Keamanan Pangan Terhadap Ekspor Produk Biofarmaka Indonesia. Jurnal Ekonomi dan Kebijakan Pembanguan, 6(1) : 41-57.
Prasetyo, Gayuh. (2009). Beberapa Aspek Perbaikan Penyemprotan Pestisida Untuk Mengendalikan Organisme Pengganggu Tanaman. Agritech, 11(2) : 69-80.

Refindra, Bayu dan Ciptaningtyas, Putri. (2016).

Metode-Metode Pengurangan Residu Pestisida pada Hasil Pertanian. Jurnal Rekayasa Kimia dan Lingkungan, 11(2) : 6171.

Agustine Eunike, dkk. (2018). Perencanaan dan Pengendalian Produksi. UB Press, Malang.

Herawati, H. \& Mulyani, D. (2016). Pengaruh Kualitas Bahan Baku Dan Proses Produksi Terhadap Kualitas Produk Pada UD. Tahu Rosydi Puspan Maron Probolinggo. Prosiding Seminar Nasional. Program Studi Manajemen Fakultas Ekonomi dan Bisnis Universitas Jember. Jember. 463-482. 